\title{
Hydrogen Sorption of Pure Mg and Niobium (V) Fluoride-Added Mg Alloys Prepared by Planetary Ball Milling in Hydrogen
}

\author{
Hye Ryoung Park ${ }^{1}$, Young Jun Kwak', Seong Ho Lee ${ }^{2}$, and Myoung Youp Song ${ }^{3}$ ** \\ ${ }^{I}$ School of Chemical Engineering, Chonnam National University, Gwangju 61 186, Republic of Korea \\ ${ }^{2}$ Department of Materials Engineering, Graduate School, Chonbuk National University, Jeonju 54896, Republic of \\ Korea \\ ${ }^{3}$ Division of Advanced Materials Engineering, Hydrogen \& Fuel Cell Research Center, Engineering Research Institute, \\ Chonbuk National University, Jeonju 54896, Republic of Korea
}

\begin{abstract}
In this work, niobium (V) fluoride was selected as an additive to heighten the hydrogen sorption rates of $\mathrm{Mg}$. Specimens of pure $\mathrm{Mg}, 5 \mathrm{wt} \%$ niobium fluoride - added $\mathrm{Mg}$, and $10 \mathrm{wt} \%$ niobium fluorideadded $\mathrm{Mg}$ were prepared by planetary ball milling in hydrogen. The hydrogen sorption properties of the specimens were then examined. An $\mathrm{Mg}$ - based hydrogen - storage alloy with an effective hydrogenstorage capacity of about $5.5 \mathrm{wt} \%$ was developed. At $593 \mathrm{~K}$ in 12 bar hydrogen at the first cycle $\left(\mathrm{C}_{\mathrm{n}}=1\right)$, the $5 \mathrm{wt} \%$ niobium fluoride - added $\mathrm{Mg}$ stored $4.37 \mathrm{wt} \%$ hydrogen in $5 \mathrm{~min}$ and $5.50 \mathrm{wt} \%$ hydrogen in $30 \mathrm{~min}$. At $593 \mathrm{~K}$ in 1.0 bar hydrogen at $\mathrm{C}_{\mathrm{n}}=1$, the $5 \mathrm{wt} \%$ niobium fluoride - added $\mathrm{Mg}$ released $2.11 \mathrm{wt} \%$ hydrogen in $10 \mathrm{~min}, 4.66 \mathrm{wt} \%$ hydrogen in $30 \mathrm{~min}$, and $5.43 \mathrm{wt} \%$ hydrogen in $60 \mathrm{~min}$. The planetary ball milling of $\mathrm{Mg}$ with $\mathrm{NbF}_{5}$ in hydrogen, which generated $\mathrm{MgF}_{2}, \mathrm{NbH}_{2}$, and $\mathrm{NbF}_{3}$, is believed to have produced imperfections both on the surface and in the interior of the $\mathrm{Mg}$ particles, created clean surfaces, and diminished the particle size of the $\mathrm{Mg}$. The $5 \mathrm{wt} \%$ niobium fluoride-added $\mathrm{Mg}$ specimen stored a larger quantity of hydrogen in $30 \mathrm{~min}$ and a larger quantity of hydrogen was released in $60 \mathrm{~min}$ compared with the $10 \mathrm{wt} \%$ niobium fluoride- added $\mathrm{Mg}$, or the pure $\mathrm{Mg}$.
\end{abstract}

(Received April 5, 2016; Accepted June 27, 2016)

Keywords: hydrogen absorbing materials, mechanical milling, microstructure, X-ray diffraction, niobium (V) fluoride-added Mg alloys

\section{INTRODUCTION}

Among many metal hydrides, magnesium hydride has been studied by many researchers since it has many advantages as a hydrogen storage material. However, the hydrogenation rate of magnesium $(\mathrm{Mg})$ and the dehydrogenation rate of magnesium hydride $\left(\mathrm{MgH}_{2}\right)$ are very low, and relatively high temperatures are required for the hydrogenation of $\mathrm{Mg}$ and the dehydrogenation of $\mathrm{MgH}_{2}[1,2]$.

A great deal of research has been performed to improve the hydrogen storage and release rates of magnesium [3-9] by alloying the magnesium with certain metals [10-12].

The hydrogen storage and release temperatures of $\mathrm{MgH}_{2}$ were decreased or the hydrogen sorption kinetics of $\mathrm{MgH}_{2}$ was improved by adding transition metal fluorides such as $\mathrm{FeF}_{3}$ [13], $\mathrm{NbF}_{5}$, and $\mathrm{TiF}_{3}$ [14], and by adding various halides including $\mathrm{ZrF}_{4}, \mathrm{TaF}_{5}, \mathrm{NbF}_{5}, \mathrm{VCl}_{3}$, and $\mathrm{TiCl}_{3}$ [15]. Malka et al.

*Corresponding Author: Myoung Youp Song [Tel: +82-63-270-2379, E-mail: songmy@jbnu.ac.kr] Copyright (c) The Korean Institute of Metals and Materials
[15] reported that, of the halides studied, $\mathrm{NbF}_{5}$ is one of the best catalysts for the hydrogen release from magnesium hydride.

Malka et al. [16] ball-milled magnesium hydride with $7 \mathrm{wt} \%$ of $\mathrm{ZrF}_{4}, \mathrm{TaF}_{5}, \mathrm{NbF}_{5}$, and $\mathrm{TiCl}_{3}$, and investigated the influence of these dopants on the hydrogen storage and released kinetics of magnesium hydride. They reported that $\mathrm{TaF}_{5}, \mathrm{NbF}_{5}$, and $\mathrm{TiCl}_{3}$ participated in the partial and full disproportionation reactions directly after milling and the first hydrogen release-storage cycle.

Malka et al. [17] reported results on the thermal stability of nanocrystalline magnesium hydride milled with $7 \mathrm{wt} \%$ of metal halide additives such as $\mathrm{ZrF}_{4}, \mathrm{NbF}_{5}, \mathrm{TaF}_{5}, \mathrm{FeF}_{2}, \mathrm{FeF}_{3}$, $\mathrm{TiCl}_{3}$ and $\mathrm{VCl}_{3}$ after 1 year of storage in a glovebox under a continuously purified argon atmosphere. The oxidation of $\mathrm{MgH}_{2}$ at low oxygen and water vapor pressures led to an increase in the hydride decomposition temperatures of the samples, compared with their initial (as-prepared) counterparts. 
Table 1. Variations in $\mathrm{H}_{\mathrm{h}}$ with $\mathrm{t}$ at $593 \mathrm{~K}$ in 12 bar hydrogen for Pure $\mathrm{Mg}, 95 \mathrm{Mg}+5 \mathrm{NbF}_{5}$, and $90 \mathrm{Mg}+10 \mathrm{NbF}_{5}$ at $\mathrm{C}_{\mathrm{n}}=1$.

\begin{tabular}{c|c|c|c|c}
\hline & \multicolumn{4}{|c}{ Stored hydrogen quantity (wt\% hydrogen) } \\
\cline { 2 - 5 } & $2.5 \mathrm{~min}$ & $5 \mathrm{~min}$ & $10 \mathrm{~min}$ & $30 \mathrm{~min}$ \\
\hline Pure $\mathrm{Mg}$ & 0.08 & & & 0.11 \\
\hline $95 \mathrm{Mg}+5 \mathrm{NbF}_{5}$ & 3.17 & 4.37 & 5.10 & 5.50 \\
\hline $90 \mathrm{Mg}+10 \mathrm{NbF}_{5}$ & 3.11 & 3.55 & 3.86 & 4.23 \\
\hline
\end{tabular}

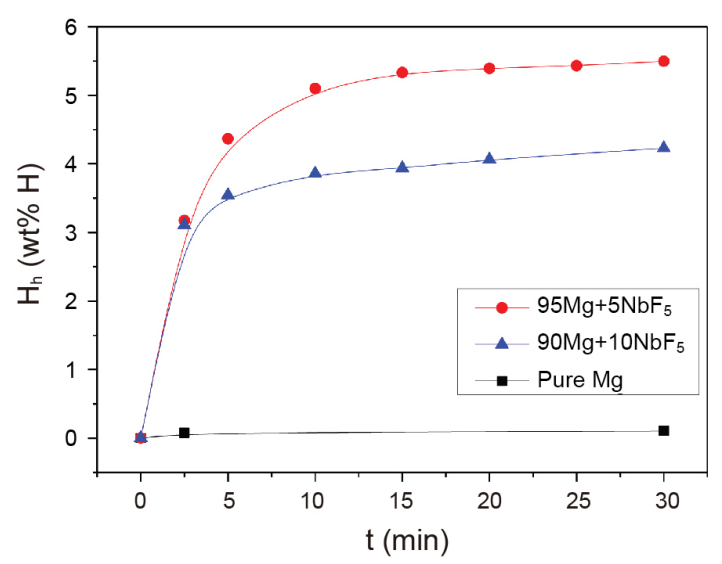

Fig. 1. Variations in $\mathrm{H}_{\mathrm{h}}$ with $\mathrm{t}$ at $593 \mathrm{~K}$ in 12 bar hydrogen for Pure $\mathrm{Mg}, 95 \mathrm{Mg}+5 \mathrm{NbF}_{5}$, and $90 \mathrm{Mg}+10 \mathrm{NbF}_{5}$ at $\mathrm{C}_{\mathrm{n}}=1$.

In the current work, niobium (V) fluoride was selected as an additive to heighten the hydrogen sorption rates (the hydrogenation and dehydrogenation rates) of $\mathrm{Mg}$. Specimens with compositions of pure $\mathrm{Mg}, 95 \mathrm{wt} \% \mathrm{Mg}+5 \mathrm{wt} \% \mathrm{NbF}_{5}$, and $90 \mathrm{wt} \% \mathrm{Mg}+10 \mathrm{wt} \% \mathrm{NbF}_{5}$ were prepared by planetary ball milling in hydrogen. The hydrogen sorption properties of the specimens were then examined. The pure $\mathrm{Mg}, 95 \mathrm{wt} \% \mathrm{Mg}$ $+5 \mathrm{wt} \% \mathrm{NbF}_{5}$, and $90 \mathrm{wt} \% \mathrm{Mg}+10 \mathrm{wt} \% \mathrm{NbF}_{5}$ samples were named Pure $\mathrm{Mg}, 95 \mathrm{Mg}+5 \mathrm{NbF}_{5}$, and $90 \mathrm{Mg}+10 \mathrm{NbF}_{5}$, respectively.

\section{EXPERIMENTAL DETAILS}

We employed pure $\mathrm{Mg}$ powder (particle size 74-149 $\mu \mathrm{m}$, purity $99.6 \%$, Alfa Aesar) and $\mathrm{NbF}_{5}$ (purity $98 \%$, Aldrich) as starting materials.

Planetary ball milling in hydrogen of about 12 bar was carried out in a planetary ball mill (Planetary Mono Mill; Pulverisette 6, Fritsch) for $6 \mathrm{~h}$ by repeating $15 \mathrm{~min}$ periods of milling interspersed with 5 min periods of rest. Hydrogen was refilled every two hours. A mixture with the desired composition was mixed in a $250 \mathrm{ml}$ stainless steel container (with 105 hardened steel balls) which was sealed hermetically. The sample weight $(8 \mathrm{~g})$ to ball weight $(360 \mathrm{~g})$ ratio was 1:45. The sample handling was performed in a glove box under Ar to prevent oxidation. The number of revolutions per minute (rpm) was 250. This process of planetary ball milling in hydrogen is explained in detail in previous works $[4,8]$.

The quantities of hydrogen absorbed by hydrogenation at $593 \mathrm{~K}$ in 12 bar hydrogen or released by dehydrogenation at $593 \mathrm{~K}$ in 1.0 bar hydrogen, as hydrogenation or dehydrogenation progressed, were measured using a volumetric method in a Sievert's type hydrogen sorption apparatus, as described previously [18]. During hydrogenation and dehydrogenation, the hydrogen pressures were maintained as nearly constant. The quantity of the specimens used to identify the hydrogenation and dehydrogenation properties was $0.5 \mathrm{~g}$.

The phases in the samples after planetary ball milling in hydrogen and after hydrogenation-de-hydrogenation cycling were analyzed by obtaining powder X-ray diffraction (XRD) patterns with $\mathrm{Cu} \mathrm{K} \alpha$ radiation in a diffractometer (Rigaku D/MAX 2500). A scanning electron microscope (SEM) (JSM-6400) was used to observe the microstructures of the powders after planetary ball milling in hydrogen and after hydrogenation-dehydrogenation cycling. Particle size distributions of the as-milled samples were analyzed using Mastersizer 3000 (Malvern Instruments, UK).

\section{RESULTS AND DISCUSSIONS}

The percentage of hydrogen stored by hydrogenation, $\mathrm{H}_{\mathrm{h}}$, was expressed with respect to the weight of the specimen. Figure 1 shows the variations in $\mathrm{H}_{\mathrm{h}}$ with $\mathrm{t}$ at $593 \mathrm{~K}$ in $12 \mathrm{bar}$ hydrogen for Pure $\mathrm{Mg}, 95 \mathrm{Mg}+5 \mathrm{NbF}_{5}$, and $90 \mathrm{Mg}+10 \mathrm{NbF}_{5}$ at the number of cycles, $C_{n}$, of $1\left(C_{n}=1\right)$. The hydrogenation rate of Pure $\mathrm{Mg}$ was very low. $\mathrm{Mg}$ stored $0.08 \mathrm{wt} \%$ hydrogen in $2.5 \mathrm{~min}$ and $0.11 \mathrm{wt} \%$ hydrogen in $30 \mathrm{~min}$ [19]. $95 \mathrm{Mg}+$ $5 \mathrm{NbF}_{5}$ and $90 \mathrm{Mg}+10 \mathrm{NbF}_{5}$ had quite high hydrogenation rates, with $95 \mathrm{Mg}+5 \mathrm{NbF}_{5}$ having a higher hydrogenation rate than $90 \mathrm{Mg}+10 \mathrm{NbF}_{5}[20,21] .95 \mathrm{Mg}+5 \mathrm{NbF}_{5}$ stored 4.37 
Table 2. Variations in $\mathrm{H}_{\mathrm{r}}$ with $\mathrm{t}$ at $593 \mathrm{~K}$ in 1.0 bar hydrogen for Pure $\mathrm{Mg}, 95 \mathrm{Mg}+5 \mathrm{NbF}_{5}$, and $90 \mathrm{Mg}+10 \mathrm{NbF}_{5}$ at $\mathrm{C}_{\mathrm{n}}=1$.

\begin{tabular}{c|c|c|c|c|c}
\hline & \multicolumn{5}{|c}{ Released hydrogen quantity (wt\% hydrogen) } \\
\cline { 2 - 6 } & $2.5 \mathrm{~min}$ & $5 \mathrm{~min}$ & $10 \mathrm{~min}$ & $30 \mathrm{~min}$ & $60 \mathrm{~min}$ \\
\hline Pure $\mathrm{Mg}$ & 0.00 & & & & 0.00 \\
\hline $95 \mathrm{Mg}+5 \mathrm{NbF}_{5}$ & 0.36 & 1.03 & 2.11 & 4.66 & 5.43 \\
\hline $90 \mathrm{Mg}+10 \mathrm{NbF}_{5}$ & 0.00 & 0.17 & 0.74 & 2.03 & 2.81 \\
\hline
\end{tabular}

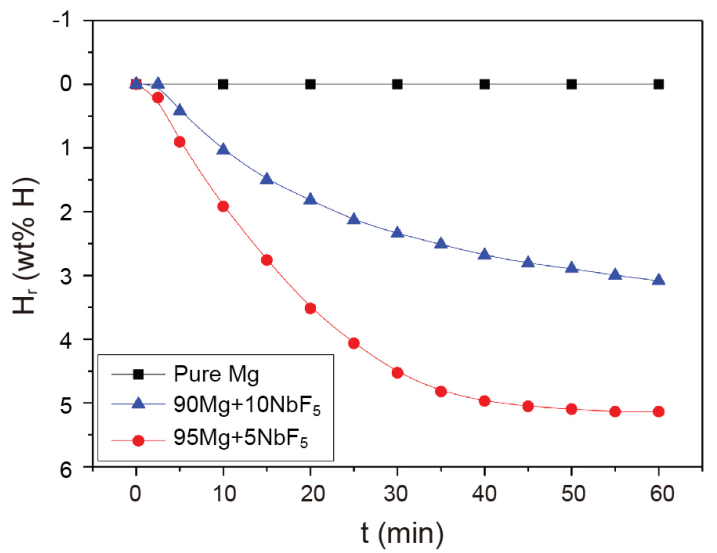

Fig. 2. Variations in $\mathrm{H}_{\mathrm{r}}$ with $\mathrm{t}$ at $593 \mathrm{~K}$ in 1.0 bar hydrogen for Pure $\mathrm{Mg}, 95 \mathrm{Mg}+5 \mathrm{NbF}_{5}$, and $90 \mathrm{Mg}+10 \mathrm{NbF} 5$ at $\mathrm{C}_{\mathrm{n}}=1$.

$\mathrm{wt} \%$ hydrogen in $5 \mathrm{~min}$ and $5.50 \mathrm{wt} \%$ hydrogen in $30 \mathrm{~min}$. $90 \mathrm{Mg}+10 \mathrm{NbF}_{5}$ stored $3.55 \mathrm{wt} \%$ hydrogen in $5 \mathrm{~min}$ and 4.23 $\mathrm{wt} \%$ hydrogen in $30 \mathrm{~min}$ [22]. Table 1 presents the variations in $\mathrm{H}_{\mathrm{h}}$ with $\mathrm{t}$ at $593 \mathrm{~K}$ in 12 bar hydrogen for Pure $\mathrm{Mg}, 95 \mathrm{Mg}$ $+5 \mathrm{NbF}_{5}$, and $90 \mathrm{Mg}+10 \mathrm{NbF}_{5}$ at $\mathrm{C}_{\mathrm{n}}=1$. It is believed that Pure Mg stored very slowly because the nucleation rate of $\mathrm{MgH}_{2}$ was very low. Milling with $\mathrm{NbF}_{5}$ in hydrogen atmosphere is believed to have facilitated the nucleation rate of $\mathrm{MgH}_{2}$ and increased the hydrogenation rate of $\mathrm{Mg}$.

We define an effective hydrogen-storage capacity as the quantity of hydrogen stored by hydrogenation in $60 \mathrm{~min}$. $95 \mathrm{Mg}+5 \mathrm{NbF}_{5}$ showed an effective hydrogen-storage capacity of about $5.5 \mathrm{wt} \%$.

The percentage of hydrogen released by dehydrogenation, $\mathrm{H}_{\mathrm{r}}$, was also expressed with respect to the weight of the specimen. The variations in $\mathrm{H}_{\mathrm{r}}$ with $\mathrm{t}$ at $593 \mathrm{~K}$ in 1.0 bar hydrogen for Pure $\mathrm{Mg}, 95 \mathrm{Mg}+5 \mathrm{NbF}_{5}$, and $90 \mathrm{Mg}+10 \mathrm{NbF}_{5}$ at $\mathrm{C}_{\mathrm{n}}=1$ are shown in Fig. 2. The dehydrogenation rate of Pure $\mathrm{Mg}$ was zero [19]. $90 \mathrm{Mg}+10 \mathrm{NbF}_{5}$ had an incubation period of $2.5 \mathrm{~min} .95 \mathrm{Mg}+5 \mathrm{NbF}_{5}$, and $90 \mathrm{Mg}+10 \mathrm{NbF}_{5}$ (after the incubation period) had quite high dehydrogenation rates, with $95 \mathrm{Mg}+5 \mathrm{NbF}_{5}$ having a higher dehydrogenation rate than $90 \mathrm{Mg}+10 \mathrm{NbF}_{5}[20,21] .95 \mathrm{Mg}+5 \mathrm{NbF}_{5}$ released 2.11 $\mathrm{wt} \%$ hydrogen in $10 \mathrm{~min}$ and $5.43 \mathrm{wt} \%$ hydrogen in $60 \mathrm{~min}$. $90 \mathrm{Mg}+10 \mathrm{NbF}_{5}$ released $0 \mathrm{wt} \%$ hydrogen in $2.5 \mathrm{~min}, 0.17$ wt $\%$ hydrogen in $5 \mathrm{~min}, 0.74 \mathrm{wt} \%$ hydrogen in $10 \mathrm{~min}$, and $2.81 \mathrm{wt} \%$ hydrogen in $60 \mathrm{~min}$ [22]. Table 2 presents the variations in $\mathrm{H}_{\mathrm{r}}$ with $\mathrm{t}$ at $593 \mathrm{~K}$ in 1.0 bar hydrogen for Pure $\mathrm{Mg}, 95 \mathrm{Mg}+5 \mathrm{NbF}_{5}$, and $90 \mathrm{Mg}+10 \mathrm{NbF}_{5}$ at $\mathrm{C}_{\mathrm{n}}=1$. Milling with $\mathrm{NbF}_{5}$ in hydrogen atmosphere is believed to have facilitated the nucleation rate of $\mathrm{Mg}$ and increased the dehydrogenation rate of $\mathrm{MgH}_{2}$.

The variation in $\mathrm{H}_{\mathrm{r}}$ with $\mathrm{t}$ according to the number of cycles, $\mathrm{C}_{\mathrm{n}}$, for $90 \mathrm{Mg}+10 \mathrm{NbF}_{5}$ at $593 \mathrm{~K}$ in 1.0 bar hydrogen was investigated [22]. At $C_{n}=1-3$, the $H_{r}$ vs. $t$ curves exhibited an incubation period of approximately $2.5 \mathrm{~min}$. As the dehydrogenation temperature increased, the equilibrium plateau pressure (which can be found in P-C-T curves) increases and the dehydrogenation rate increased. As the dehydrogenation temperature increases, the gap between the equilibrium plateau pressure and the applied hydrogen pressure for dehydrogenation (1.0 bar hydrogen in this figure) increases, which is the driving force for dehydrogenation [18]. The incubation periods are believed to have appeared due to a small driving force for dehydrogenation. Tanguy et al. [23] reported the equilibrium plateau pressures in the $\mathrm{Mg}-\mathrm{H}$ system at various temperatures. With their results, the relation between the equilibrium plateau pressure $\left(\mathrm{P}_{\mathrm{eq}}\right)$ and temperature in the $\mathrm{Mg}-\mathrm{H}$ system was obtained as the following:

$$
\ln \mathrm{Peq}_{\text {(bar })}=17.65-9,844 / \mathrm{T}
$$

Stampfer et al. [24] also reported a similar relation between the equilibrium plateau pressure $\left(\mathrm{P}_{\mathrm{eq}}\right)$ and temperature in the $\mathrm{Mg}-\mathrm{H}$ system. From the equation (1), the equilibrium plateau pressure was calculated as 2.87 bar. After the incubation period, the initial dehydrogenation rate increased from $\mathrm{C}_{n}=1$ to $C_{n}=3$. The quantity of hydrogen released for $60 \mathrm{~min}, \mathrm{H}_{\mathrm{r}}(60$ 
Table 3. Variations in $H_{r}$ with $t$ at $C_{n}=1$ and $C_{n}=3$ for $90 M g+$ $10 \mathrm{NbF}_{5}$ at $593 \mathrm{~K}$ in 1.0 bar hydrogen.

\begin{tabular}{c|c|c|c|c|c}
\hline \multirow{2}{*}{} & \multicolumn{5}{|c}{ Released hydrogen quantity (wt \% hydrogen) } \\
\cline { 2 - 6 } & $2.5 \mathrm{~min}$ & $5 \mathrm{~min}$ & $10 \mathrm{~min}$ & $30 \mathrm{~min}$ & $60 \mathrm{~min}$ \\
\hline $\mathrm{C}_{\mathrm{n}}=1$ & 0.00 & 0.17 & 0.74 & 2.03 & 2.81 \\
\hline $\mathrm{C}_{\mathrm{n}}=3$ & 0.00 & 0.42 & 1.03 & 2.34 & 3.08 \\
\hline
\end{tabular}

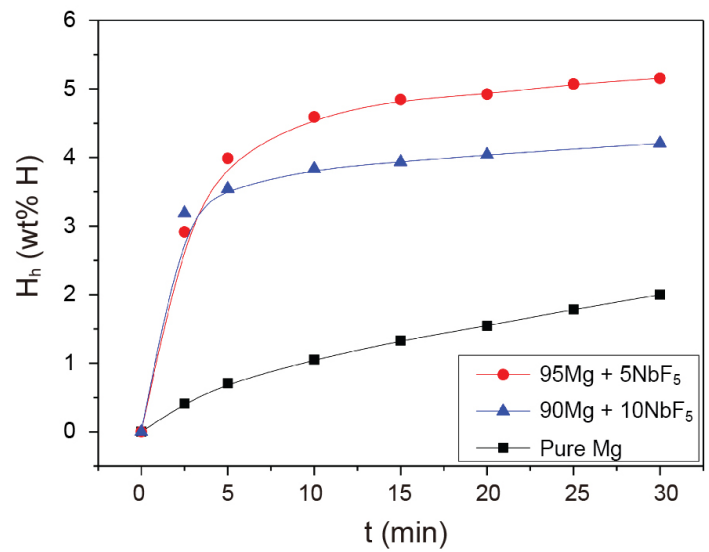

Fig. 3. Variations in $\mathrm{H}_{\mathrm{h}}$ with $\mathrm{t}$ at $593 \mathrm{~K}$ in 12 bar hydrogen for Pure $\mathrm{Mg}, 95 \mathrm{Mg}+5 \mathrm{NbF}_{5}$, and $90 \mathrm{Mg}+10 \mathrm{NbF}_{5}$ at $\mathrm{C}_{\mathrm{n}}=3$.

min), decreased from $C_{n}=1$ to $C_{n}=2$, and then increased from $C_{n}=2$ to $C_{n}=3$. At $C_{n}=1$, the specimen released 0.74 $\mathrm{wt} \%$ hydrogen in $10 \mathrm{~min}$ and $2.81 \mathrm{wt} \%$ hydrogen in $60 \mathrm{~min}$. At $\mathrm{C}_{\mathrm{n}}=3$, the specimen released $1.03 \mathrm{wt} \%$ hydrogen in 10 min and $3.08 \mathrm{wt} \%$ hydrogen in $60 \mathrm{~min}$. The variation in $\mathrm{H}_{\mathrm{r}}$ with $t$ according to the number of cycles showed that the $\mathrm{H}_{\mathrm{r}}$ vs. $\mathrm{t}$ curve for $90 \mathrm{Mg}+10 \mathrm{NbF}_{5}$ at $593 \mathrm{~K}$ in 1.0 bar hydrogen did not change significantly from $C_{n}=2$ to $C_{n}=3$, i.e., it was stabilized at $\mathrm{C}_{\mathrm{n}}=3$. We therefore compared the $\mathrm{H}_{\mathrm{h}}$ vs. $\mathrm{t}$ curves and $\mathrm{H}_{\mathrm{r}}$ vs. $\mathrm{t}$ curves for Pure $\mathrm{Mg}, 95 \mathrm{Mg}+5 \mathrm{NbF}_{5}$, and $90 \mathrm{Mg}+10 \mathrm{NbF}_{5}$ at $\mathrm{C}_{\mathrm{n}}=3$. Table 3 shows the variation in $\mathrm{H}_{\mathrm{r}}$ with $t$ at $C_{n}=1$ and $C_{n}=3$ for $90 \mathrm{Mg}+10 \mathrm{NbF}_{5}$ at $593 \mathrm{~K}$ in 1.0 bar hydrogen.

The variations in $\mathrm{H}_{\mathrm{h}}$ with $\mathrm{t}$ at $593 \mathrm{~K}$ in 12 bar hydrogen for Pure $\mathrm{Mg}, 95 \mathrm{Mg}+5 \mathrm{NbF}_{5}$, and $90 \mathrm{Mg}+10 \mathrm{NbF}_{5}$ at $\mathrm{C}_{\mathrm{n}}=3$ are shown in Fig. 3. Pure Mg had a much higher hydrogenation rate at $\mathrm{C}_{\mathrm{n}}=3$ than at $\mathrm{C}_{\mathrm{n}}=1[19] .95 \mathrm{Mg}+5 \mathrm{NbF}_{5}$ had the highest initial hydrogenation rate and the largest quantity of hydrogen stored for $30 \mathrm{~min}$, followed in order by $90 \mathrm{Mg}+$ $10 \mathrm{NbF}_{5}$ and $\mathrm{Mg}$. Pure $\mathrm{Mg}$ stored $0.41 \mathrm{wt} \%$ hydrogen in 2.5 $\min , 0.71 \mathrm{wt} \%$ hydrogen in $5 \mathrm{~min}$, and $2.00 \mathrm{wt} \%$ hydrogen in
Table 4. Variations in $\mathrm{H}_{\mathrm{h}}$ with $\mathrm{t}$ at $593 \mathrm{~K}$ in 12 bar hydrogen for Pure $\mathrm{Mg}, 95 \mathrm{Mg}+5 \mathrm{NbF}_{5}$, and $90 \mathrm{Mg}+10 \mathrm{NbF}_{5}$ at $\mathrm{C}_{\mathrm{n}}=3$.

\begin{tabular}{c|c|c|c|c}
\hline & \multicolumn{4}{|c}{ Stored hydrogen quantity (wt\% hydrogen) } \\
\cline { 2 - 5 } & $2.5 \mathrm{~min}$ & $5 \mathrm{~min}$ & $10 \mathrm{~min}$ & $30 \mathrm{~min}$ \\
\hline Pure $\mathrm{Mg}$ & 0.41 & 0.71 & 1.05 & 2.00 \\
\hline $95 \mathrm{Mg}+5 \mathrm{NbF}_{5}$ & 2.92 & 3.99 & 4.59 & 5.16 \\
\hline $90 \mathrm{Mg}+10 \mathrm{NbF}_{5}$ & 3.19 & 3.54 & 3.83 & 4.21 \\
\hline
\end{tabular}

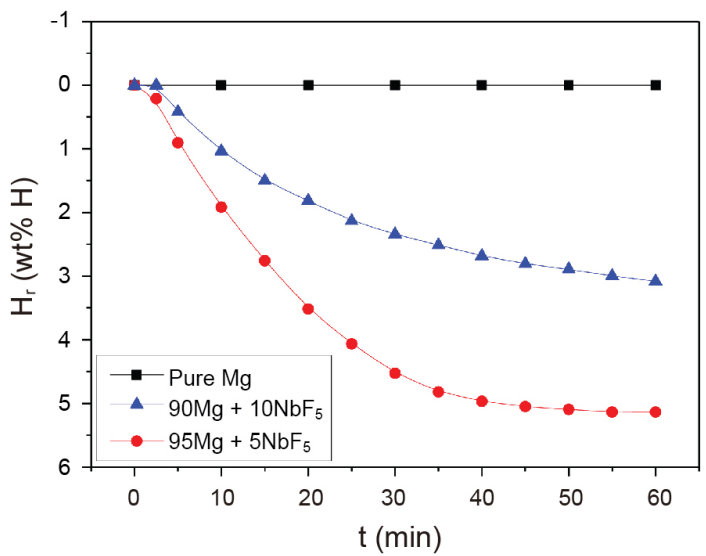

Fig. 4. Variations in $\mathrm{H}_{\mathrm{r}}$ with $\mathrm{t}$ at $593 \mathrm{~K}$ in 1.0 bar hydrogen for Pure $\mathrm{Mg}, 95 \mathrm{Mg}+5 \mathrm{NbF}_{5}$, and $90 \mathrm{Mg}+10 \mathrm{NbF}_{5}$ at $\mathrm{C}_{\mathrm{n}}=3$.

30 min. $95 \mathrm{Mg}+5 \mathrm{NbF}_{5}$ stored $3.99 \mathrm{wt} \%$ hydrogen in $5 \mathrm{~min}$ and $5.16 \mathrm{wt} \%$ hydrogen in $30 \mathrm{~min} .90 \mathrm{Mg}+10 \mathrm{NbF}_{5}$ stored $3.54 \mathrm{wt} \%$ hydrogen in $5 \mathrm{~min}$ and $4.21 \mathrm{wt} \%$ hydrogen in 30 min [22]. Table 4 presents the variations in $\mathrm{H}_{\mathrm{h}}$ with $\mathrm{t}$ at $593 \mathrm{~K}$ in 12 bar hydrogen for Pure $\mathrm{Mg}, 95 \mathrm{Mg}+5 \mathrm{NbF}_{5}$, and $90 \mathrm{Mg}+$ $10 \mathrm{NbF}_{5}$ at $\mathrm{C}_{\mathrm{n}}=3$. Hydrogenation-dehydrogenation cycling increased the initial hydrogenation rate and increased the quantity of hydrogen stored in $30 \mathrm{~min}$ of the Pure $\mathrm{Mg}$ due to the expansion of the material by hydrogenation and contraction of the material by dehydrogenation. Expansion and contraction of the material are considered to have produced imperfections, created clean surfaces, and diminished the $\mathrm{Mg}$ particle size.

Figure 4 shows the variations in $\mathrm{H}_{\mathrm{r}}$ with $\mathrm{t}$ at $593 \mathrm{~K}$ in 1.0 bar hydrogen for Pure $\mathrm{Mg}, 95 \mathrm{Mg}+5 \mathrm{NbF}_{5}$, and $90 \mathrm{Mg}+$ $10 \mathrm{NbF}_{5}$ at $\mathrm{C}_{\mathrm{n}}=3 . \mathrm{Mg}$ did not release hydrogen [19]. This is believed to be due to the small driving force for dehydrogenation. $90 \mathrm{Mg}+10 \mathrm{NbF}_{5}$ had an incubation period of $2.5 \mathrm{~min} .95 \mathrm{Mg}+5 \mathrm{NbF}_{5}$ and $90 \mathrm{Mg}+10 \mathrm{NbF}_{5}$ (after the incubation period) had quite high dehydrogenation rates, with $95 \mathrm{Mg}+5 \mathrm{NbF}_{5}$ having a higher dehydrogenation rate than 
Table 5. Variations in $\mathrm{H}_{\mathrm{r}}$ with $\mathrm{t}$ at $593 \mathrm{~K}$ in 1.0 bar hydrogen for Pure $\mathrm{Mg}, 95 \mathrm{Mg}+5 \mathrm{NbF}_{5}$, and $90 \mathrm{Mg}+10 \mathrm{NbF}_{5}$ at $\mathrm{C}_{\mathrm{n}}=3$.

\begin{tabular}{c|c|c|c|c|c}
\hline & \multicolumn{5}{|c}{ Released hydrogen quantity (wt\% hydrogen) } \\
\cline { 2 - 6 } & $2.5 \mathrm{~min}$ & $5 \mathrm{~min}$ & $10 \mathrm{~min}$ & $30 \mathrm{~min}$ & $60 \mathrm{~min}$ \\
\hline Pure $\mathrm{Mg}$ & 0.00 & & & & 0.00 \\
\hline $95 \mathrm{Mg}+5 \mathrm{NbF}_{5}$ & 0.21 & 0.91 & 1.92 & 4.53 & 5.14 \\
\hline $90 \mathrm{Mg}+10 \mathrm{NbF}_{5}$ & 0.00 & 0.42 & 1.03 & 2.34 & 3.08 \\
\hline
\end{tabular}
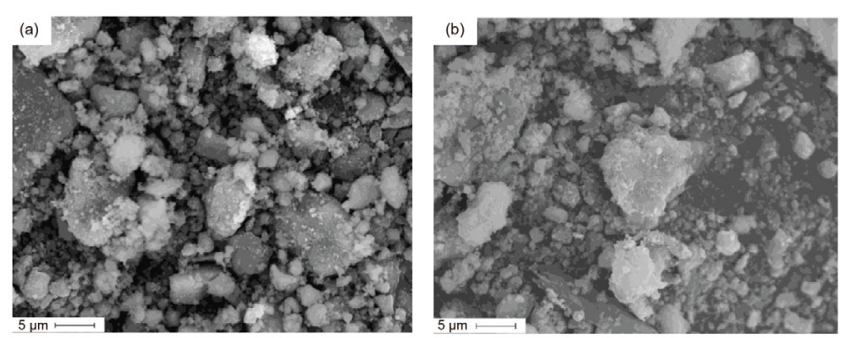

Fig. 5. SEM images of (a) $95 \mathrm{Mg}+5 \mathrm{NbF}_{5}$ and (b) $90 \mathrm{Mg}+10 \mathrm{NbF}_{5}$ after planetary ball milling in hydrogen.

$90 \mathrm{Mg}+10 \mathrm{NbF}_{5}[20,21] .95 \mathrm{Mg}+5 \mathrm{NbF}_{5}$ released $1.92 \mathrm{wt} \%$ hydrogen in $10 \mathrm{~min}$ and $5.14 \mathrm{wt} \%$ hydrogen in $60 \mathrm{~min}$. $90 \mathrm{Mg}+10 \mathrm{NbF}_{5}$ released $1.03 \mathrm{wt} \%$ hydrogen in $10 \mathrm{~min}$ and $3.08 \mathrm{wt} \%$ hydrogen in $60 \mathrm{~min}$ [22]. Table 5 presents the variations in $\mathrm{H}_{\mathrm{r}}$ with $\mathrm{t}$ at $593 \mathrm{~K}$ in 1.0 bar hydrogen for Pure $\mathrm{Mg}, 95 \mathrm{Mg}+5 \mathrm{NbF}_{5}$, and $90 \mathrm{Mg}+10 \mathrm{NbF}_{5}$ at $\mathrm{C}_{\mathrm{n}}=3$.

As the number of cycles increased from $C_{n}=1$ to $C_{n}=3$, the initial hydrogenation rate and the quantity of hydrogen absorbed in $30 \mathrm{~min}$ of $95 \mathrm{Mg}+5 \mathrm{NbF}_{5}$ decreased. As the number of cycles for $90 \mathrm{Mg}+10 \mathrm{NbF}_{5}$ increased from $\mathrm{C}_{\mathrm{n}}=1$ to $\mathrm{C}_{\mathrm{n}}=3$, the initial hydrogenation rate increased and the quantity of hydrogen stored in $30 \mathrm{~min}$ decreased. As the number of cycles increased from $C_{n}=1$ to $C_{n}=3$, the initial dehydrogenation rate and the quantity of hydrogen released in $60 \mathrm{~min}$ of $95 \mathrm{Mg}+5 \mathrm{NbF}_{5}$ decreased. As the number of cycles for $90 \mathrm{Mg}+10 \mathrm{NbF}_{5}$ increased from $\mathrm{C}_{\mathrm{n}}=1$ to $\mathrm{C}_{\mathrm{n}}=3$, after the incubation period, the initial dehydrogenation rate and the quantity of hydrogen released in $60 \mathrm{~min}$ increased. The overall trends of the hydrogenation and dehydrogenation rates and the quantities of hydrogen stored in $30 \mathrm{~min}$ and released in 60 min showed that the activation of $95 \mathrm{Mg}+5 \mathrm{NbF}_{5}$ and $90 \mathrm{Mg}+10 \mathrm{NbF}_{5}$ was not required.

Figure 5 shows the SEM images of $95 \mathrm{Mg}+5 \mathrm{NbF}_{5}$ and $90 \mathrm{Mg}+10 \mathrm{NbF}_{5}$ after planetary ball milling in hydrogen. $95 \mathrm{Mg}+5 \mathrm{NbF}_{5}$ and $90 \mathrm{Mg}+10 \mathrm{NbF}_{5}$ had a wide range of
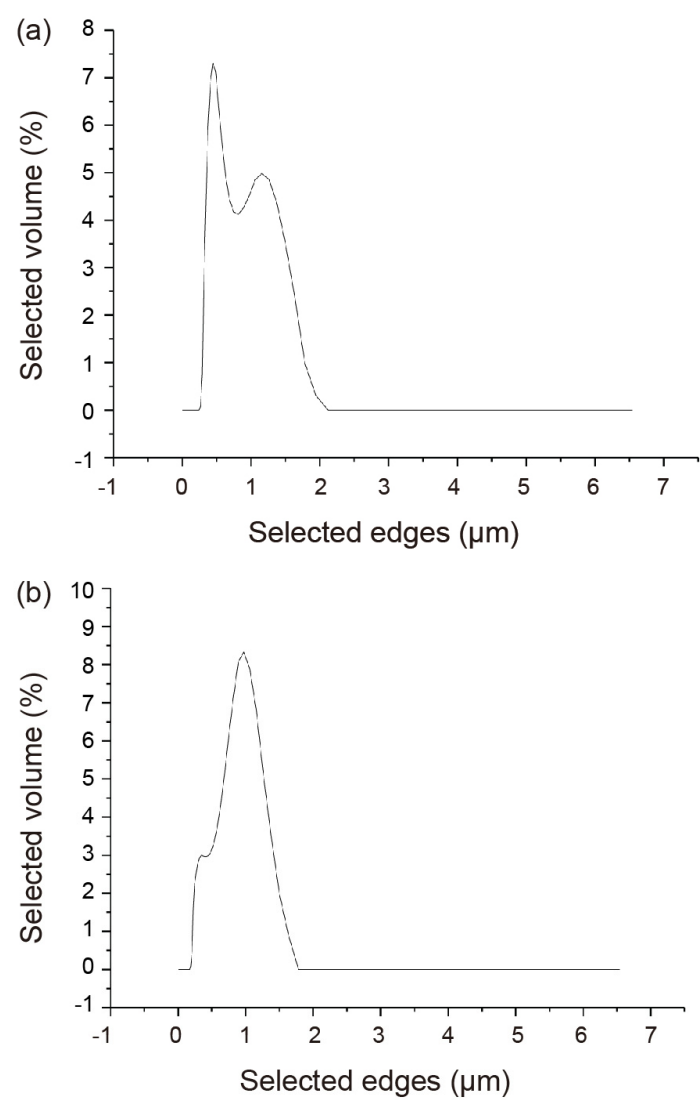

Fig. 6. Particle size distributions of (a) $95 \mathrm{Mg}+5 \mathrm{NbF}_{5}$ and (b) $90 \mathrm{Mg}+10 \mathrm{NbF}_{5}$ after planetary ball milling in hydrogen.

particle sizes and the particles of these samples had fine particles on their surfaces. Pure Mg had particles of various sizes, the surfaces of which were very flat. The particles had a few imperfections [20,21]. $95 \mathrm{Mg}+5 \mathrm{NbF}_{5}$ had the largest number of fine particles, followed in order by $90 \mathrm{Mg}+$ $10 \mathrm{NbF}_{5}$ and Pure Mg. This agrees well with the results that Pure $\mathrm{Mg}$ absorbed hydrogen very slowly, Pure Mg did not release hydrogen, and $95 \mathrm{Mg}+5 \mathrm{NbF}_{5}$ and $90 \mathrm{Mg}+10 \mathrm{NbF}_{5}$ had quite high hydrogenation and dehydrogenation rates, with $95 \mathrm{Mg}+5 \mathrm{NbF}_{5}$ having higher hydrogenation and dehydrogenation rates than $90 \mathrm{Mg}+10 \mathrm{NbF}_{5}$.

Figure 6 shows the particle size distributions of $95 \mathrm{Mg}+$ $5 \mathrm{NbF}_{5}$ and $90 \mathrm{Mg}+10 \mathrm{NbF}_{5}$ after planetary ball milling in hydrogen. These two samples have relatively narrow particle size distributions, with particle sizes between $0 \mu \mathrm{m}$ and about $2 \mu \mathrm{m} .95 \mathrm{Mg}+5 \mathrm{NbF}_{5}$ had the strongest peak at $0.5 \mu \mathrm{m}$ and the second strongest peak at $1.2 \mu \mathrm{m} .90 \mathrm{Mg}+10 \mathrm{NbF}_{5}$ had the strongest peak at $1.0 \mu \mathrm{m}$ and the second strongest peak at 0.3 

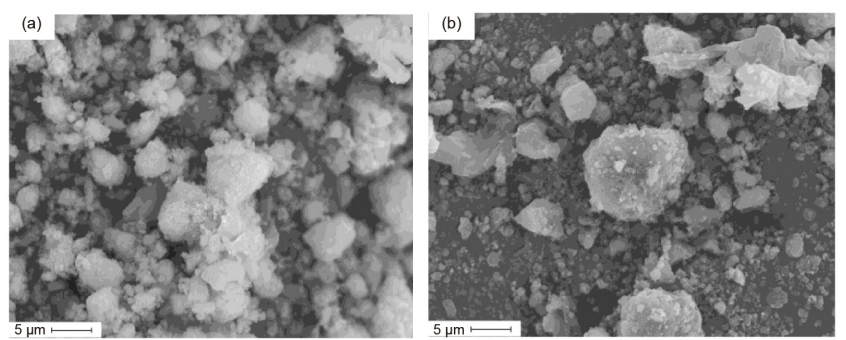

Fig. 7. $\mathrm{SEM}$ images of (a) $95 \mathrm{Mg}+5 \mathrm{NbF}_{5}$ and (b) $90 \mathrm{Mg}+$ $10 \mathrm{NbF}_{5}$ from which hydrogen was released at $\mathrm{C}_{n}=3$.

$\mu \mathrm{m}$. The average particle size of the as-milled $95 \mathrm{Mg}+5 \mathrm{NbF}_{5}$ was analyzed as $0.732 \pm 0.390 \mu \mathrm{m}$ and that of the as-milled $90 \mathrm{Mg}+10 \mathrm{NbF}_{5}$ was analyzed as $0.742 \pm 0.372 \mu \mathrm{m}$. The average particle size of the as-milled $95 \mathrm{Mg}+5 \mathrm{NbF}_{5}$ was slightly smaller than that of the as-milled $90 \mathrm{Mg}+10 \mathrm{NbF}_{5}$. The surface areas of the as-milled $95 \mathrm{Mg}+5 \mathrm{NbF}_{5}$ and the as-milled $90 \mathrm{Mg}+10 \mathrm{NbF}_{5}$ were 10.33 and $10.50 \mathrm{~m}^{2} / \mathrm{cm}^{3}$, respectively.

The SEM images of $95 \mathrm{Mg}+5 \mathrm{NbF}_{5}$ and $90 \mathrm{Mg}+10 \mathrm{NbF}_{5}$ dehydrogenated at $C_{n}=3$ are shown in Fig. 7. Pure Mg had large particles, the surfaces of which were quite flat. The particles had more imperfections and cracks than those of the Pure Mg sample after planetary ball milling in hydrogen $[20,21]$. During hydrogenation, the material expands, and during dehydrogenation, it contracts. The increase and decrease in the volumes of $\mathrm{Mg}$ particles with hydrogenation and dehydrogenation are considered to induce the formation of imperfections and cracks on the particles. The formation of more imperfections and cracks explains why the Pure $\mathrm{Mg}$ specimen at $\mathrm{C}_{\mathrm{n}}=3$ had a higher hydrogenation rate than the Pure $\mathrm{Mg}$ specimen after planetary ball milling in hydrogen. $95 \mathrm{Mg}+5 \mathrm{NbF}_{5}$ had small particles and large particles, but had quite a homogeneous particle size distribution, with fine particles on the particle surfaces. $90 \mathrm{Mg}+10 \mathrm{NbF}_{5}$ had small particles, large particles, and very large particles with fine particles on the particle surfaces. The very large particles had flat surfaces. $95 \mathrm{Mg}+5 \mathrm{NbF}_{5}$ had the smallest particle sizes, followed in order by $90 \mathrm{Mg}+10 \mathrm{NbF}_{5}$ and Pure $\mathrm{Mg}$. This agrees well with the result that $95 \mathrm{Mg}+5 \mathrm{NbF}_{5}$ had the highest hydrogenation and dehydrogenation rates, followed in order by $90 \mathrm{Mg}+10 \mathrm{NbF}_{5}$ and Pure Mg. $95 \mathrm{Mg}+5 \mathrm{NbF}_{5}$ and $90 \mathrm{Mg}+$ $10 \mathrm{NbF}_{5}$ had generally larger particles than $95 \mathrm{Mg}+5 \mathrm{NbF}_{5}$ and $90 \mathrm{Mg}+10 \mathrm{NbF}_{5}$ after planetary ball milling in hydrogen, explaining why they had lower hydrogenation and dehydrogenation rates than after planetary ball milling in hydrogen. It is believed that this resulted from the coalescence of particles because the samples were maintained at a relatively high temperature of $593 \mathrm{~K}$ during hydrogenation-dehydrogenation cycling.

The powder XRD patterns of Pure $\mathrm{Mg}, 95 \mathrm{Mg}+5 \mathrm{NbF}_{5}$, and $90 \mathrm{Mg}+10 \mathrm{NbF}_{5}$ after planetary ball milling in hydrogen were investigated $[2,22,25]$. The powder XRD pattern of Pure Mg after planetary ball milling in hydrogen exhibited $\mathrm{Mg}$ and a very small amount of $\beta-\mathrm{MgH}_{2}$, which was formed by the reaction of $\mathrm{Mg}$ with hydrogen during planetary ball milling in hydrogen. The powder XRD patterns of $95 \mathrm{Mg}+5 \mathrm{NbF}_{5}$ and $90 \mathrm{Mg}+10 \mathrm{NbF}_{5}$ after planetary ball milling in hydrogen had quite a high background, indicating that the samples were somewhat amorphous. $95 \mathrm{Mg}+5 \mathrm{NbF}_{5}$ and $90 \mathrm{Mg}+10 \mathrm{NbF}_{5}$ after planetary ball milling in hydrogen included $\mathrm{Mg}, \beta$ $-\mathrm{MgH}_{2}$, and small amounts of $\gamma-\mathrm{MgH}_{2}, \mathrm{NbH}_{2}, \mathrm{MgF}_{2}$, and $\mathrm{NbF}_{3} . \beta-\mathrm{MgH}_{2}$ and $\gamma-\mathrm{MgH}_{2}$ were formed by the reaction of $\mathrm{Mg}$ with the hydrogen during planetary ball milling in hydrogen. $\beta-\mathrm{MgH}_{2}$ is a tetragonal $\mathrm{MgH}_{2}$ which can be synthesized in a low hydrogen pressure. $\gamma-\mathrm{MgH}_{2}$ is an orthorhombic $\mathrm{MgH}_{2}$, which is a form of the high-pressure $\mathrm{MgH}_{2}$. The reaction among $\mathrm{Mg}, \mathrm{NbF}_{5}$, and $\mathrm{H}_{2}$ generated $\mathrm{MgF}_{2}, \mathrm{NbH}_{2}$, and $\mathrm{NbF}_{3}$.

The power XRD patterns of Pure $\mathrm{Mg}$ from which hydrogen was released at $\mathrm{C}_{\mathrm{n}}=9$, and $95 \mathrm{Mg}+5 \mathrm{NbF}_{5}$ and $90 \mathrm{Mg}+$ $10 \mathrm{NbF}_{5}$ from which hydrogen was released at $\mathrm{C}_{\mathrm{n}}=3$ were examined [22,25]. The powder XRD pattern of $\mathrm{Mg}$ from which hydrogen was released at $C_{n}=9$ showed that the specimen included $\mathrm{Mg}$ and a very small amount of $\beta-\mathrm{MgH}_{2}$. The powder XRD pattern of $95 \mathrm{Mg}+5 \mathrm{NbF}_{5}$ from which hydrogen was released at $\mathrm{C}_{\mathrm{n}}=3$ showed that the specimen included $\mathrm{Mg}$, small amounts of $\beta-\mathrm{MgH}_{2}$ and $\mathrm{MgO}$, and very small amounts of $\mathrm{MgF}_{2}$ and $\mathrm{NbH}_{2}$. The powder XRD pattern of $90 \mathrm{Mg}+10 \mathrm{NbF}_{5}$ from which hydrogen was released at $\mathrm{C}_{\mathrm{n}}=$ 3 showed $\mathrm{Mg}, \beta-\mathrm{MgH}_{2}$, a small amount of $\mathrm{MgO}$, and very small amounts of $\mathrm{MgF}_{2}$ and $\mathrm{NbH}_{2}$. In the $95 \mathrm{Mg}+5 \mathrm{NbF}_{5}$ and $90 \mathrm{Mg}+10 \mathrm{NbF}_{5}$ specimens, $\mathrm{MgF}_{2}$ and $\mathrm{NbH}_{2}$ stayed changeless after dehydrogenation. 


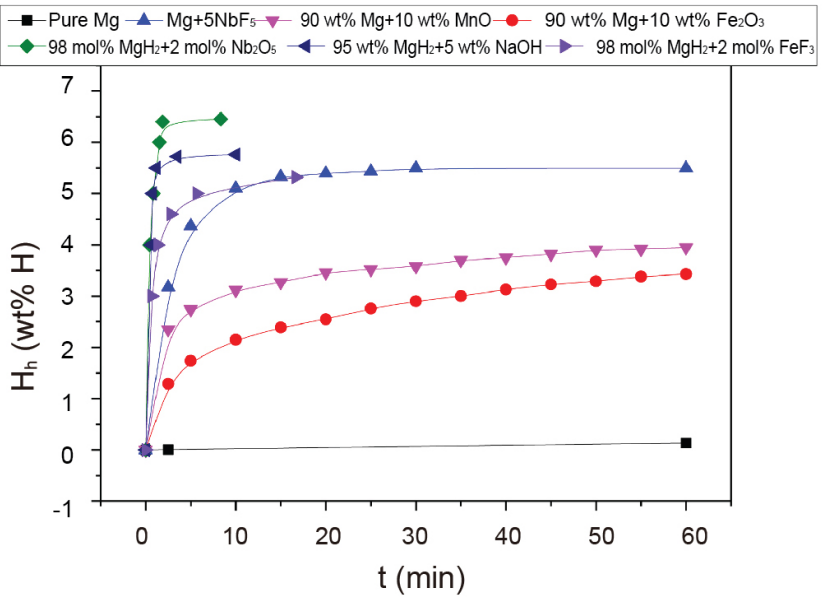

Fig. 8. $\mathrm{H}_{\mathrm{h}}$ vs. $\mathrm{t}$ curves at $\mathrm{C}_{\mathrm{n}}=1$ for Pure $\mathrm{Mg}$ [19], $95 \mathrm{Mg}+5 \mathrm{NbF}_{5}$, $90 \mathrm{wt} \% \mathrm{Mg}+10 \mathrm{wt} \% \mathrm{MnO}$ [27], and $90 \mathrm{wt} \% \mathrm{Mg}+10 \mathrm{wt} \% \mathrm{Fe}_{2} \mathrm{O}_{3}$ [27] at $593 \mathrm{~K}$ in 12 bar hydrogen, for $98 \mathrm{~mol} \% \mathrm{MgH}_{2}+2 \mathrm{~mol} \%$ $\mathrm{Nb}_{2} \mathrm{O}_{5}$ at $573 \mathrm{~K}$ in 10 bar hydrogen [28], for $95 \mathrm{wt} \% \mathrm{MgH}_{2}+5 \mathrm{wt} \%$ $\mathrm{NaOH}$ at $573 \mathrm{~K}$ in an initial pressure of 17 bar hydrogen [29], and for $98 \mathrm{~mol} \% \mathrm{MgH}_{2}+2 \mathrm{~mol} \% \mathrm{FeF}_{3}$ at $573 \mathrm{~K}$ in 10 bar hydrogen [13]

Ball milling was performed in a hydrogen atmosphere. The sample may be contaminated from the hardened steel balls. The prepared sample may contain Fe. However, it is believed that this $\mathrm{Fe}$ does not have negative effects on hydrogenation and dehydrogenation of the samples. Residual stress is considered to be released during heating for hydrogenation and dehydrogenation and during hydrogenation-de hydrogenation cycling.

The planetary ball milling of $\mathrm{Mg}$ with $\mathrm{NbF}_{5}$ in hydrogen, which formed $\mathrm{MgF}_{2}, \mathrm{NbH}_{2}$, and $\mathrm{NbF}_{3}$ by reaction with hydrogen, is believed to have produced imperfections both on the surface and in the interior of the $\mathrm{Mg}$ particles, created clean surfaces, and diminished the $\mathrm{Mg}$ particle size. The particles have defects which are believed to be dislocations and interfaces between $\mathrm{Mg}$ and the other phases. Fecht et al. [26] reported that at a high strain rate, a dense network of dislocations (shear bands) forms which then deforms the material, leading to the reduction in particle size. The production of imperfections is believed to have promoted nucleation, the creation of clean surfaces is thought to have improved reactivity of particles with hydrogen, and the diminution in the $\mathrm{Mg}$ particle size is believed to have decreased the diffusion distances of hydrogen atoms. These influences heightened the hydrogenation and dehydrogenation rates of $\mathrm{Mg}$. The formed $\mathrm{MgF}_{2}, \mathrm{NbH}_{2}$, and $\mathrm{NbF}_{3}$ are considered to have enhanced these influences.

The average particle size of the as-milled $95 \mathrm{Mg}+5 \mathrm{NbF}_{5}$ was slightly smaller than that of the as-milled $90 \mathrm{Mg}+$ $10 \mathrm{NbF}_{5}$, showing that the effects of milling (production of imperfections, creation of clean surfaces, and diminution in the $\mathrm{Mg}$ particle size) with $5 \mathrm{wt} \% \mathrm{NbF}_{5}$ are slightly stronger than those of milling with $10 \mathrm{wt}^{\%} \mathrm{NbF}_{5}$. The larger content of $\mathrm{NbF}_{5}$ in the $90 \mathrm{Mg}+10 \mathrm{NbF}_{5}$ specimen as compared with the $95 \mathrm{Mg}+5 \mathrm{NbF}_{5}$ specimen decreased the fraction of $\mathrm{Mg}$ which could store and release hydrogen in the $90 \mathrm{Mg}+$ $10 \mathrm{NbF}_{5}$ specimen. These two points explain why $95 \mathrm{Mg}+$ $5 \mathrm{NbF}_{5}$ had a higher initial hydrogenation rate, a larger quantity of hydrogen stored for $30 \mathrm{~min}$, a higher initial dehydrogenation rate, and a larger quantity of hydrogen released in $60 \mathrm{~min}$ than $90 \mathrm{Mg}+10 \mathrm{NbF}_{5}$.

Figure 8 shows the $\mathrm{H}_{\mathrm{h}}$ vs. $\mathrm{t}$ curves at $\mathrm{C}_{\mathrm{n}}=1$ for Pure $\mathrm{Mg}$ [19], $95 \mathrm{Mg}+5 \mathrm{NbF}_{5}, 90 \mathrm{wt} \% \mathrm{Mg}+10 \mathrm{wt} \% \mathrm{MnO}$ [27], and 90 $\mathrm{wt} \% \mathrm{Mg}+10 \mathrm{wt} \% \mathrm{Fe}_{2} \mathrm{O}_{3}$ [27] at $593 \mathrm{~K}$ in 12 bar hydrogen, for $98 \mathrm{~mol} \% \mathrm{MgH}_{2}+2 \mathrm{~mol} \% \mathrm{Nb}_{2} \mathrm{O}_{5}$ at $573 \mathrm{~K}$ in 10 bar hydrogen [ 28], for $95 \mathrm{wt} \% \mathrm{MgH}_{2}+5 \mathrm{wt} \% \mathrm{NaOH}$ at $573 \mathrm{~K}$ in an initial pressure of 17 bar hydrogen [29], and for $98 \mathrm{~mol}^{\circ} \mathrm{MgH}_{2}+2$ $\mathrm{mol} \% \mathrm{FeF}_{3}$ at $573 \mathrm{~K}$ in 10 bar hydrogen [13]. Pure $\mathrm{Mg}$ stored hydrogen very slowly. $95 \mathrm{Mg}+5 \mathrm{NbF}_{5}$ had a larger quantity of hydrogen stored in 10 min than $98 \mathrm{~mol}_{\mathrm{o}} \mathrm{MgH}_{2}+2 \mathrm{~mol} \%$ $\mathrm{FeF}_{3}, 90 \mathrm{wt} \% \mathrm{Mg}+10 \mathrm{wt}^{\%} \% \mathrm{MnO}, 90 \mathrm{wt} \% \mathrm{Mg}+10 \mathrm{wt}^{\%} \%$ $\mathrm{Fe}_{2} \mathrm{O}_{3}$, and Pure $\mathrm{Mg}$ but a smaller quantity of hydrogen stored in $10 \mathrm{~min}$ than $95 \mathrm{wt}^{\%} \mathrm{MgH}_{2}+5 \mathrm{wt} \% \mathrm{NaOH}$ and $98 \mathrm{~mol} \%$ $\mathrm{MgH}_{2}+2 \mathrm{~mol} \% \mathrm{Nb}_{2} \mathrm{O}_{5} .98 \mathrm{~mol} \% \mathrm{MgH}_{2}+2 \mathrm{~mol} \% \mathrm{Nb}_{2} \mathrm{O}_{5}$ had the highest initial hydrogenation rate, followed in order by 95 wt $\% \mathrm{MgH}_{2}+5 \mathrm{w} \% \mathrm{NaOH}, 98 \mathrm{~mol} \% \mathrm{MgH}_{2}+2 \mathrm{~mol} \% \mathrm{FeF}_{3}$, $95 \mathrm{Mg}+5 \mathrm{NbF}_{5}, 90 \mathrm{wt} \% \mathrm{Mg}+10 \mathrm{wt} \% \mathrm{MnO}, 90 \mathrm{wt} \% \mathrm{Mg}+10$ wt $\% \mathrm{Fe}_{2} \mathrm{O}_{3}$, and Pure Mg. $98 \mathrm{~mol} \% \mathrm{MgH}_{2}+2 \mathrm{~mol} \% \mathrm{Nb}_{2} \mathrm{O}_{5}$ stored $4.00 \mathrm{wt} \%$ hydrogen in $0.42 \mathrm{~min}, 6.40 \mathrm{wt} \%$ hydrogen in $1.88 \mathrm{~min}$, and $6.45 \mathrm{wt} \%$ hydrogen in $8.33 \mathrm{~min} .95 \mathrm{wt} \% \mathrm{MgH}_{2}$ $+5 \mathrm{w} \% \mathrm{NaOH}$ stored $4.00 \mathrm{wt} \%$ hydrogen in $0.63 \mathrm{~min}, 5.50$ $\mathrm{wt} \%$ hydrogen in $1.17 \mathrm{~min}$, and $5.76 \mathrm{wt} \%$ hydrogen in $10 \mathrm{~min}$. $98 \mathrm{~mol} \% \mathrm{MgH}_{2}+2 \mathrm{~mol} \% \mathrm{FeF}_{3}$ stored $3.00 \mathrm{wt} \%$ hydrogen in $0.67 \mathrm{~min}, 4.60 \mathrm{wt} \%$ hydrogen in $2.8 \mathrm{~min}$, and $5.32 \mathrm{wt} \%$ hydrogen in $16.67 \mathrm{~min}$. $95 \mathrm{Mg}+5 \mathrm{NbF}_{5}$ stored $3.17 \mathrm{wt} \%$ hydrogen in $2.5 \mathrm{~min}, 4.37 \mathrm{wt} \%$ hydrogen in $5 \mathrm{~min}, 5.10 \mathrm{wt} \%$ 
hydrogen in $10 \mathrm{~min}$, and $5.50 \mathrm{wt} \%$ hydrogen in $30 \mathrm{~min} .90$ $\mathrm{wt} \% \mathrm{Mg}+10 \mathrm{wt} \% \mathrm{MnO}$ stored $2.74 \mathrm{wt} \%$ hydrogen in $5 \mathrm{~min}$, $3.12 \mathrm{wt} \%$ hydrogen in $10 \mathrm{~min}, 3.58 \mathrm{wt} \%$ hydrogen in $30 \mathrm{~min}$, and $3.95 \mathrm{wt} \%$ hydrogen in $60 \mathrm{~min}$. Pure $\mathrm{Mg}$ stored $0.08 \mathrm{wt} \%$ hydrogen in $2.5 \mathrm{~min}$, and $0.14 \mathrm{wt} \%$ hydrogen in $60 \mathrm{~min}$. The use of $\mathrm{Mg}$ instead of $\mathrm{MgH}_{2}$ is considered to have led to the smaller quantity of hydrogen stored in $30 \mathrm{~min}$ by $95 \mathrm{Mg}+$ $5 \mathrm{NbF}_{5}$ than by $95 \mathrm{wt} \% \mathrm{MgH}_{2}+5 \mathrm{wt} \% \mathrm{NaOH}$ and $98 \mathrm{~mol} \%$ $\mathrm{MgH}_{2}+2 \mathrm{~mol} \% \mathrm{Nb}_{2} \mathrm{O}_{5}$. In order to increase the hydrogenation and dehydrogenation rates and the effective hydrogen-storage capacity of $\mathrm{NbF}_{5}$-added $\mathrm{Mg}$ samples, we suggest adding nano-sized $\mathrm{NbF}_{5}$, decreasing the content of $\mathrm{NbF}_{5}$, or using $\mathrm{MgH}_{2}$ as a starting material instead of $\mathrm{Mg}$.

\section{CONCLUSIONS}

In the current work, $\mathrm{NbF}_{5}$ was selected as an additive to heighten the hydrogenation and dehydrogenation rates of $\mathrm{Mg}$ in the current work. Specimens with compositions of Pure $\mathrm{Mg}, 95 \mathrm{Mg}+5 \mathrm{NbF}_{5}$, and $90 \mathrm{Mg}+10 \mathrm{NbF}_{5}$ were prepared by planetary ball milling in hydrogen. The hydrogenation and dehydrogenation properties of the specimens were then examined. At $593 \mathrm{~K}$ in 12 bar hydrogen at the first cycle, $95 \mathrm{Mg}+5 \mathrm{NbF}_{5}$ absorbed $4.37 \mathrm{wt} \%$ hydrogen in $5 \mathrm{~min}$ and $5.50 \mathrm{wt} \%$ hydrogen in $30 \mathrm{~min}$. At $593 \mathrm{~K}$ in 1.0 bar hydrogen at the first cycle, $95 \mathrm{Mg}+5 \mathrm{NbF}_{5}$ released $2.11 \mathrm{wt} \%$ hydrogen in $10 \mathrm{~min}$ and $5.43 \mathrm{wt} \%$ hydrogen in $60 \mathrm{~min}$. Activations of $95 \mathrm{Mg}+5 \mathrm{NbF}_{5}$ and $90 \mathrm{Mg}+10 \mathrm{NbF}_{5}$ were not needed. The planetary ball milling in hydrogen of $\mathrm{Mg}$ with $\mathrm{NbF}_{5}$, which generated $\mathrm{MgF}_{2}, \mathrm{NbH}_{2}$, and $\mathrm{NbF}_{3}$, is believed to have produced imperfections, created clean surfaces, and diminished the $\mathrm{Mg}$ particle size. The average particle size of the as-milled $95 \mathrm{Mg}+5 \mathrm{NbF}_{5}$ was slightly smaller than that of the as-milled $90 \mathrm{Mg}+10 \mathrm{NbF}_{5}$, showing that the effects of milling with $5 \mathrm{wt} \% \mathrm{NbF}_{5}$ are slightly stronger than those of milling with $10 \mathrm{wt} \% \mathrm{NbF}_{5}$. The larger content of $\mathrm{NbF}_{5}$ in the $90 \mathrm{Mg}+10 \mathrm{NbF}_{5}$ specimen than in the $95 \mathrm{Mg}+5 \mathrm{NbF}_{5}$ specimen decreased the fraction of $\mathrm{Mg}$ which could store and release hydrogen in the $90 \mathrm{Mg}+10 \mathrm{NbF}_{5}$ specimen. These two points explain why $95 \mathrm{Mg}+5 \mathrm{NbF}_{5}$ had a larger quantity of hydrogen stored in $30 \mathrm{~min}$ and a larger quantity of hydrogen released in $60 \mathrm{~min}$ than $90 \mathrm{Mg}+10 \mathrm{NbF}_{5}$.

\section{ACKNOWLEDGEMENTS}

This research was supported by Basic Science Research Program through the National Research Foundation (NRF) of Korea funded by the Ministry of Education, Science and Technology (Grant number 2011-0023566).

\section{REFERENCES}

1. S. -H. Hong and M. Y. Song, Met. Mater. Int. 21, 422 (2015).

2. M. Y. Song, Y. J. Kwak, S. H. Lee and H. R. Park, Bull. Mater. Sci. 37, 831 (2014).

3. S. H. Lee, Y. J. Kwak, H. R. Park and M. Y. Song, Korean J. Met. Mater. 53, 187 (2015).

4. Y. J. Kwak, S. N. Kwon, S. H. Lee, I. W. Park and M. Y. Song, Korean J. Met. Mater. 53, 500 (2015).

5. Y. J. Kwak, S. N. Kwon and M. Y. Song, Met. Mater. Int. 21, 971 (2015).

6. Y. J. Kwak, S. N. Kwon and M. Y. Song, Korean J. Met. Mater. 53, 808 (2015).

7. D. R. Mumm, Y. J. Kwak, H. R. Park and M. Y. Song, Korean J. Met. Mater. 53, 904 (2015).

8. S. H. Lee, H. R. Park and M. Y. Song, Korean J. Met. Mater. 53, 133 (2015).

9. K. I. Kim and T. W. Hong, Met. Mater. Int. 17, 1001 (2011).

10. J. J. Reilly and R. H. Wiswall, Inorg. Chem. 6, 2220 (1967).

11. J. J. Reilly and R. H. Wiswall Jr, Inorg. Chem. 7, 2254 (1968).

12. E. Akiba, K. Nomura, S. Ono and S. Suda, Int. J. Hydrogen Energy 17, 787 (1982).

13. A. R. Yavari, A. LeMoulec, F. R. de Castro, S. Deledda S, O. Friedrichs, W. J. Botta, G. Vaughan, T. Klassen, A. Fernandez and A. Kvick, Scrip. Mater. 52, 719 (2005).

14. S. A. Jin, J. P. Ahn, J. H. Shim, Y. W. Cho and K. W. Yi, J. Power Sources 172, 859 (2007).

15. I. E. Malka, T. Czujko and J. Bystrzycki, Int. J. Hydrog. Energy 35, 1706 (2010).

16. I. E. Malka, M. Pisarek, T. Czujko and J. Bystrzycki, Int. J. Hydrog. Energy 36, 12909 (2011).

17. I. E. Malka and J. Bystrzycki, Int. J. Hydrogen Energy 39, 335 (2014).

18. M. Y. Song, S. H. Baek, J. -L. Bobet, J. Song and S. H. Hong, Int. J. Hydrog. Energy 35, 10366 (2010).

19. Y. J. Kwak, S. H. Lee, H. R. Park, and M. Y. Song, Korean J. Met. Mater. 52, 957 (2014).

20. Y. J. Kwak, S. H. Lee, H. R. Park, and M. Y. Song, J. Nanoscience Nanotechnology 16, 10508 (2016). 
21. M.Y. Song, Y.J. Kwak, S.H. Lee, and H.R. Park, Met. Mater. Int. 21, 208 (2015).

22. Y. J. Kwak, J. Song, and D. R. Mumm, Korean J. Mater. Res. 23, 562 (2013).

23. B. Tanguy, J. L. Soubeyroux, M. Pezat, J. Portier and P. Hagenmuller, Mater. Res. Bull. 11, 1441 (1976).

24. J. F. Stampfer Jr., C. E. Holley Jr. and J. F. Suttle, J. Am. Chem. Soc. 82, 3504 (1960).

25. S. H. Lee, Y. J. Kwak, H. R. Park and M. Y. Song, Int. J. Hydrogen Energy 39, 16486 (2014).

26. H. J. Fecht, E. Hellstern, Z. Fu and W. L. Johnson, $A$
Metall. Mater. Trans. A-Phys. Matall. Mater. Sci. 21A, 2333 (1990).

27. M. Y. Song, I. H. Kwon, S. N. Kwon, C. G. Park, S. H. Hong, J. S. Bae and D. R. Mumm, J. Alloy Compd. 415, 266 (2006).

28. O. Friedrichs, F. Aguey-Zinsou, J. R. A. Fernandez, J. C. Sanchez-Lopez, A. Justo, T. Klassen, R. Bormann and A. Fernandez, Acta Mater. 54, 105, (2006).

29. H wang, J. Zhang, J. W. Liu, L. Z. Ouyang and M. Zhu, Int. J. Hydrog. Energy 38, 10932 (2013). 